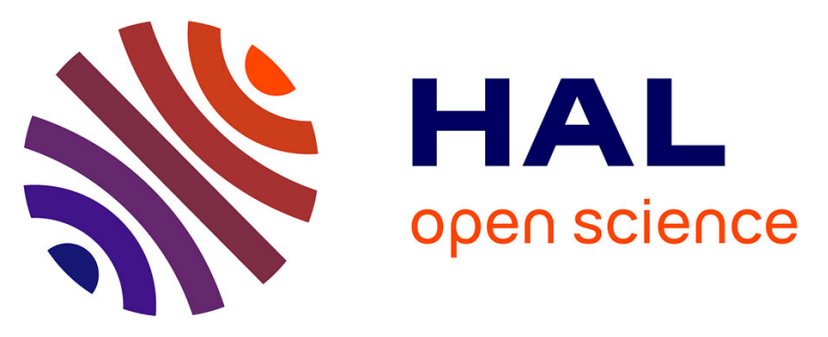

\title{
Coplanar waveguide monopole antenna on artificial magnetic conductor for body-worn wireless communication systems
}

Fanamperana Tsitoha Andriamiharivolamena, Pierre Lemaitre-Auger, S. Tedjini, Franck Tirard

\section{To cite this version:}

Fanamperana Tsitoha Andriamiharivolamena, Pierre Lemaitre-Auger, S. Tedjini, Franck Tirard. Coplanar waveguide monopole antenna on artificial magnetic conductor for body-worn wireless communication systems. 2014 IEEE International Symposium on Antennas and Propagation \& USNC/URSI National Radio Science Meeting, Jul 2014, Memphis, United States. pp.438-439, 10.1109/aps.2014.6904551 . hal-02388144

\section{HAL Id: hal-02388144 \\ https://hal.univ-grenoble-alpes.fr/hal-02388144}

Submitted on 1 Dec 2019

HAL is a multi-disciplinary open access archive for the deposit and dissemination of scientific research documents, whether they are published or not. The documents may come from teaching and research institutions in France or abroad, or from public or private research centers.
L'archive ouverte pluridisciplinaire HAL, est destinée au dépôt et à la diffusion de documents scientifiques de niveau recherche, publiés ou non, émanant des établissements d'enseignement et de recherche français ou étrangers, des laboratoires publics ou privés. 


\section{Coplanar waveguide monopole antenna on artificial magnetic conductor for body-worn wireless communication systems}

\author{
T. Andriamiharivolamena ${ }^{1,2}$, P. Lemaitre-Auger ${ }^{1}$, \\ ${ }^{1}$ University Grenoble Alpes - LCIS \\ 50 Barthélémy de Laffemas, 26000 Valence, FRANCE \\ tsitoha.andriamiharivolamena@1cis.grenoble-inp.fr, \\ pierre.lemaitre-auger@lcis.grenoble-inp.fr,
}

\begin{abstract}
We report in this paper the design and the realization of a monopole antenna directly placed over an artificial magnetic conductor (AMC) without the need of additional space between them. Simulation results and measurements are in good agreement and show that the antenna performances are as good as the best ones reported so far in literature while having a smaller volume. The antenna works at $1.916 \mathrm{GHz}$ with a bandwidth of $8 \%$. The adaptation of the antenna is $-35 \mathrm{~dB}$. Measurement of the antenna gain is $4.7 \mathrm{dBi}$ with a front-to-back radiation ratio of $15.8 \mathrm{~dB}$. Simulation results also show that the AMC isolates well the monopole from of the body: the localized SAR value calculated with $1 \mathrm{~g}$ of tissue is $0.34 \mathrm{~W} / \mathrm{kg}$ with an injected power of $1 \mathrm{~W}$. The antenna with the $\mathrm{AMC}$ is well adapted for wearable applications.
\end{abstract}

\section{INTRODUCTION}

Electronic communications systems are present in almost everyone's life today. A lot of people are dreaming to reduce their impact on our mobility by integrating those systems in our clothes, including the antenna. But antenna integration close to a body immediately raised the question of the body protection and of the radiating efficiency of the antenna. One solution that attracted a lot of attention in recent years is the use of high impedance surfaces (HIS). That solution was thus studied for wearable antennas but also for applications where antennas are placed closed to printed circuit boards. Indeed, a HIS placed behind the antenna increases the front-to-back radiation ratio, thus reducing the SAR in the presence of a human body and the coupling between the antenna and the electronic circuit. Also, a HIS reduces the dimensions of the antenna [1].

One of the difficulty when using an antenna close to a HIS is that the antenna impedance is greatly modified by the HIS. That was clearly showed by some studies [2, 3]. More specifically, the first study [2] showed that a dipole has a reflection coefficient less than $-9.54 \mathrm{~dB}$ for phase values of the reflected wave $(\varphi)$ comprised between $\left[-110^{\circ},-155^{\circ}\right]$ and $\left[40^{\circ}\right.$, $\left.115^{\circ}\right]$, results that were confirmed by the second study [3] for a antenna-HIS distance of $0.02 \lambda$, where $\lambda$ is the wavelength. The conclusion of those studies is that a dipole close to a HIS has a low reflection coefficient when the impedance of the HIS is finite and purely imaginary. In this case, the HIS is a reactive surface impedance (RIS). This was theoretically shown in [4] thanks to the image theory: the minimal coupling between a dipole and its image is obtained when the HIS becomes a RIS.

\author{
S. Tedjini ${ }^{1}$, F. Tirard ${ }^{2}$ \\ ${ }^{2}$ Safran Sagem \\ 100 avenue de Paris, 91344 Massy, FRANCE \\ franck.tirard@sagem.com \\ smail.tedjini@lcis.grenoble-inp.fr,
}

Those results were obtained for dipole antennas. However, the realization of dipole antennas close to a RIS on fabrics is difficult because of the presence of vias and baluns.

Monopole antennas seem to be simpler to realize on fabrics. They were recently used close to HIS without any via [5-7]. However, in all studies reported so far, an additional spacer made out of foam (1 to $2 \mathrm{~mm}$ thick) was required to obtain a good antenna adaptation. In this work, we will show that it is possible to obtain very good performances with a monopole antenna over an HIS without the need of an additional spacer: the antenna substrate is directly placed over the patch structure of the HIS. In the present case, the HIS works at its resonance frequency and, for that reason, it is called an AMC [8]. The antenna and the AMC structure have the smallest volume (relative to the wavelength) reported so far.

The type of AMC used in this work is the mushroom one [9] but without the vias. That structure was first studied in [4, $8,10]$ and it was shown that it has a wider bandwidth $(19.35 \%)$ than other types of AMC like: cross, meandered cell or interdigited patch [8].

The optimized structure will be presented in the first part of the text. Then, simulation and experimental results will be presented and compared.

\section{STRUTURE OF THE ANTENNA AND OF THE HIS}

The antenna is a monopole fed by a coplanar transmission line structure. The conductor used is copper (thickness : $16 \mu \mathrm{m}$ ) and the substrate used is FR4, $1.6 \mathrm{~mm}$ thick, $\mathcal{E}_{r}$ of 4.3 and $\tan (\delta)=0.01$. The AMC is a network of square metal patches periodically placed on a FR4 substrate $3.2 \mathrm{~mm}$ thick. A ground plane is located under the substrate. No via between the patches and the ground plane is used. The antenna and the HIS structures are shown in Fig.1 and the values of the different physical parameter are given in Table 1 .

The whole structure was optimized with CST Microwave studio. Good results were obtained for a monopole length of $22.25 \mathrm{~mm}$ at the resonant frequency of $1.944 \mathrm{GHz}$. The total surface area of the whole structure is $86.5 \mathrm{~mm} \times 86.5 \mathrm{~mm}$. This is equivalent to $0.55 \lambda \times 0.55 \lambda$. The reflection coefficient is $44 \mathrm{~dB}$. It is worth noting here that three different solutions were in fact found but only one is presented here, the one working at the resonant frequency of the HIS. 


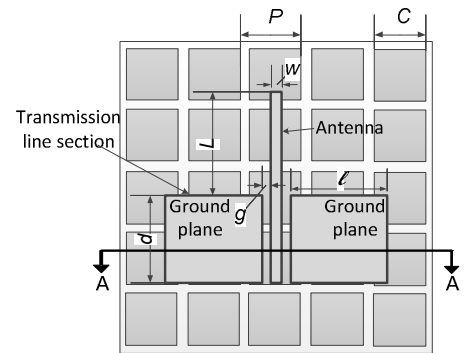

(a)

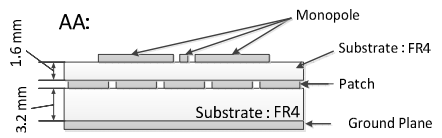

(b)

Fig. 1. The monopole antenna over the HIS. (a) Top view. (b) Side view.

TABle I. GeOMEtrical Parameters of the Monopole ANTENNA AND OF THE HIS

\begin{tabular}{|l|l|l|l|}
\hline Parameters & Value (mm) & Parameters & Value (mm) \\
\hline$W$ & 3 & $\ell$ & 28.2 \\
\hline$g$ & 0.3 & $C$ & 17 \\
\hline$d$ & 25 & $P$ & 0.3 \\
\hline
\end{tabular}

\section{EXPERIMENTAL RESULTS}

To validate the simulations, the structure was realized. The Fig. 2 shows the measured and simulated reflection coefficients in free space. Both results are quite close to each other. The measured resonance frequency is $1.916 \mathrm{GHz}$. It is slightly shifted to smaller frequency compared to the one predicted by the simulation by $1.4 \%$. The adaptation is good: the measured one is $-35 \mathrm{~dB}$. This is better than published results [5-7]. The measured bandwidth is $8 \%$ at $-10 \mathrm{~dB}$. This value is two times larger than the one published in [7]. Measurements were also done in the presence of a human body and the differences with simulations results are still negligible.

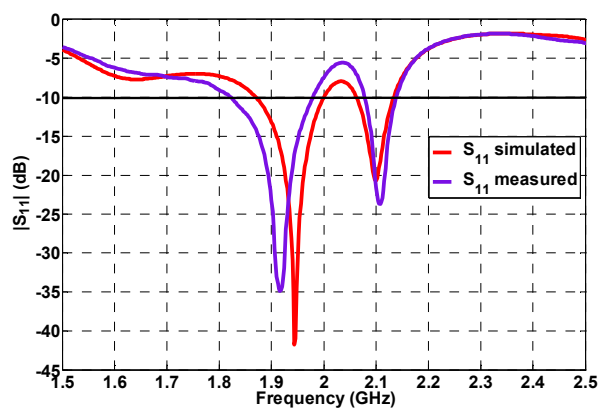

Fig. 2. Measured and simulated reflection coefficients.

The radiation pattern was also measured. The Fig. 3 shows the simulations and the experimental results. The agreement is good. The measured gain is $4.3 \mathrm{dBi}$. Those measurements were repeated in the presence of the human body and agreements are once again good.

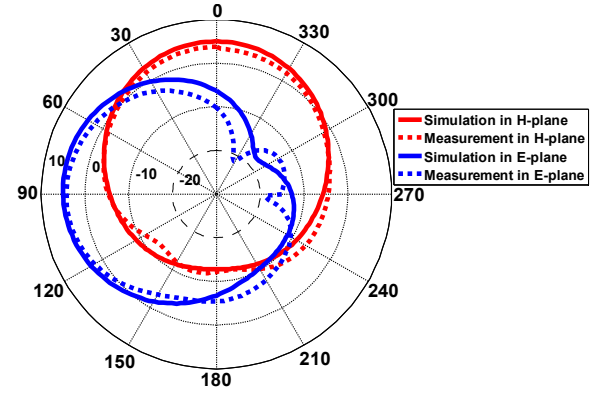

Fig. 3. Measured \& simulated Radiation patterns : $1.916 \mathrm{GHz}$.

\section{CONCLUSION}

A printed monopole placed directly above a HSI was presented. It is designed for wearable wireless application. The volume obtained is the smallest reported one and the performances obtained are as good or even better than the reported results up to now.

\section{ACKNOWLEDGEMENT}

This work is part of the project GIANTE funded by a RAPID-DGA contract. The authors are grateful for Dr. PierreFrançois LOUVIGNE for his valuable support and advice. The authors would like to thank the company ARDEJE for its contribution to a part of this work.

\section{REFERENCES}

[1] F. Yang, A. Aminian, and Y. Rahmat-Samii, "A novel surface-wave antenna design using a thin periodically loaded ground plane," Microw. Opt. Technol. Lett., vol. 47, no. 3, pp. 240-245, Nov. 2005.

[2] M. F. Abedin, M. Ali, "Effects of EBG reflection phase profiles on the input impedance and bandwidth of ultrathin directional dipoles," IEEE Trans. Antennas Propagat., vol. 53, no. 11, pp. 3664-3672, Nov. 2005.

[3] F. Yang and Y. Rahmat-Samii, "Reflection phase characterizations of the EBG ground plane for low profile wire antenna applications," IEEE Trans. Antennas Propagat., vol. 51, no. 10, pp. 2691-2703, Oct. 2003.

[4] H. Mosallaei and K. Sarabandi, "Antenna miniaturization and bandwidth enhancement using a reactive impedance substrate," IEEE Trans. Antennas Propagat., vol. 52, no. 9, pp. 2403-2414, Sep. 2004.

[5] M. Mantash, A. C. Tarot, S. Collardey, K. Mahdjoubi, "Investigation of flexible textile antennas and AMC reflectors," International Journal of Antennas and Propagation, 2012, 236505 (10 pp.). 2012.

[6] H. R. Raad, A. I. Abbosh, H. M. Al-Rizzo, D. G. Rucker, "Flexible and Compact AMC Based Antenna for Telemedicine Applications," IEEE Trans. Antennas Propagat., vol. 61, no. 2, pp. 524-531, Feb. 2013.

[7] S. Zhu and R. Langley, "Dual-Band Wearable Textile Antenna on an EBG Substrate," IEEE Trans. Antennas Propagat., vol. 57, no. 4, pp. 926-935, Apr. 2009

[8] F. Costa, S. Genovesi, and A. Monorchio, "On the Bandwidth of HighImpedance Frequency Selective Surfaces," Antennas Wireless Propag. Lett., vol. 8, pp. 1341-1344, 2009.

[9] D. Sievenpiper, Z. Lijun, R. F. J. Broas, N. G. Alexopolous, and E. Yablonovitch, "High-impedance electromagnetic surfaces with a forbidden frequency band," IEEE Trans. Microw. Theory Tech., vol. 47, pp. 2059-2074, Nov. 1999.

[10] G. Goussetis, A. P. Feresidis, and J. C. Vardaxoglou, "Tailoring the AMC and EBG characteristics of periodic metallic arrays printed on grounded dielectric substrate," IEEE Trans. Antennas Propagat., vol. 54, no. 1, pp. 82-89, Jan. 2006 